\title{
Metal Imbalance in Neurodegenerative Diseases with a Specific Concern to the Brain of Multiple Sclerosis Patients
}

\author{
Jean-Philippe Dales ${ }^{1,2, *}$ and Sophie Desplat-Jégo ${ }^{1,3}$ \\ 1 Institute of Neurophysiopathology, CNRS, INP, Aix-Marseille University, 13005 Marseille, France; \\ sophie.DESPLAT@ap-hm.fr \\ 2 Assistance Publique-Hôpitaux de Marseille, Hôpital Nord, Pavillon Etoile, Pôle de Biologie, \\ Service d'anatomie-pathologie, CEDEX 20, 13915 Marseille, France \\ 3 Assistance Publique-Hôpitaux de Marseille, Hôpital de la Conception, Pôle de Biologie, \\ Service d'Immunologie, 13005 Marseille, France \\ * Correspondence: JeanPhilippe.Dales@ap-hm.fr
}

Received: 21 September 2020; Accepted: 19 November 2020; Published: 30 November 2020

\begin{abstract}
There is increasing evidence that deregulation of metals contributes to a vast range of neurodegenerative diseases including multiple sclerosis (MS). MS is a chronic inflammatory disease of the central nervous system (CNS) manifesting disability and neurological symptoms. The precise origin of MS is unknown, but the disease is characterized by focal inflammatory lesions in the CNS associated with an autoimmune reaction against myelin. The treatment of this disease has mainly been based on the prescription of immunosuppressive and immune-modulating agents. However, the rate of progressive disability and early mortality is still worrisome. Metals may represent new diagnostic and predictive markers of severity and disability as well as innovative candidate drug targets for future therapies. In this review, we describe the recent advances in our understanding on the role of metals in brain disorders of neurodegenerative diseases and MS patients.
\end{abstract}

Keywords: multiple sclerosis; central nervous system; chemical element; metal; oxidative stress

\section{Introduction}

Metals are vital for several biochemical processes and are required for normal central nervous system (CNS) functioning [1-3]. They are natural constituents of the earth's soil and are disseminated into the biosphere through human activities [4]. Some metals are of bio-importance to health and their daily medicinal and dietary allowances have been recommended. They must be obtained from the environment and appropriately bound or compartmentalized within cells and tissues for use in biochemical pathways. They are essential cofactors for enzymes and structural elements notably implicated in the synthesis, stability, and maintenance of myelin [5-7]. Dietary intakes of these metals have to be maintained at regulatory limits, as excesses can result in toxicity. Other metals considered as xenobiotics have no known bio-importance in human physiology and their consumption even at very low concentrations can be detrimental. The leading mechanisms by which metals may induce autoimmune process are not well known, but they seem to imply a molecular mimicry, which occurs when similarities between foreign-derived and self-peptides favor an activation of autoreactive immune cells in susceptible individuals. It has been postulated that some xenobiotic metals may generate neoantigens by altering self-proteins both directly and indirectly or involve the exposure of parts of self-proteins not previously presented to the immune system, i.e., cryptic epitopes, which are therefore identified as non-self $[8,9]$. Thus, these metals can initiate an inappropriate $\mathrm{T}$ cell response in several 
ways, such as post-translational conformational modification of a bound peptide or altered antigen presentation to the Human leukocyte antigen (HLA) molecules.

There is now increasing evidence that deregulation of metals, such as iron, copper, and zinc homeostasis, contributes to a vast range of neurodegenerative diseases [10-14]. Multiple sclerosis (MS) is a chronic immune-mediated disease of the CNS in which an inflammatory process results in myelin sheath destruction, gliosis, and neurodegeneration. Although the origin of MS is still unknown, genetic predisposition and environmental toxicity may activate the immune system against CNS cells. Some metals such as mercury from dental amalgam have been discussed in the past as controversial etiologic factor in MS $[15,16]$. In addition, patients with relapsing remitting and secondary progressive MS have been shown to excrete large amounts of aluminum in their urine $[17,18]$. In MS patients, deregulation of metals in the serum, the cerebrospinal fluid (CSF), and the brain have been reported, however it is unclear whether it represents an initial or a subsequent event of the disease [19-21].

The aim of this work is to provide a summary of the current literature around the whole metal abnormalities in neurodegenerative disease patients and a meaningful review of the studies of these abnormalities in the blood and CNS in MS patients. Previous reviews in this area have largely focused on the potential role for isolated or a few metals in the pathogenesis, but to our knowledge, no study has encompassed a comprehensive analysis of the entirety of metals. It appears useful to provide a global view of the known metal imbalance, because metals are in a fine tuning equilibrium with each other in human tissues and deep understanding of the complexity of this imbalance may implicate to explore metals in their wholeness. Otherwise, literature studies about magnetic resonance imaging (MRI) techniques, which have been previously well reviewed will be out of the scope of this work. In this context, we will also develop perspectives on the future of "metals and MS" based around the bio-imaging of metals to further understand the mechanisms of the disease and possibly to identify potential targets for innovative treatments.

\section{Essential Metals in the Normal Brain}

\subsection{Metal Homeostasis and Global Content}

Essential metals are those chemical elements that are required for the normal functioning of biological tissues such as brain parenchyma. These metals in biological systems may be broadly divided into two groups: essential alkali and alkaline-earth metals such as sodium, potassium, magnesium, and calcium; essential transition metals such as copper, manganese, iron, zinc, and less abundant chromium, cobalt, molybdenum, or nickel. These metals are incorporated in a whole host of physiological processes such as electron and oxygen transport, protein modification, neurotransmitter synthesis, redox reactions, cell adhesion, protein, and carbohydrate metabolism and immune response.

Transition metals are known to be present in protein active sites as metabolic cofactors for structural and catalytic functions, and they are increasingly also recognized for a second messenger role in cell signaling $[22,23]$. In the CNS, iron, copper, and zinc metals act as essential cofactors in metalloproteins with unique importance in myelin synthesis, maintenance of oligodendrocytes, and neurotransmitter synthesis $[1,6,7,13,22-27]$. For example, the functions of iron include oxygen homeostasis, energy metabolism, DNA synthesis and repair, myelination of the white matter as well as synthesis, uptake, and degradation of neurotransmitters. Copper's functions include synthesis of catecholamines, activation of neuropeptides and hormones, antioxidant defense, connective tissue production, synaptic transmission, and immune function [28-30]. Manganese appears mainly bound to the astrocyte-specific enzyme glutamine synthetase, and it can have profound effects on microglia and astrocytes by amplifying the activation of a proinflammatory response [31-33]. Zinc is a structural and catalytic component contributing to the efficient performance of over 2000 transcription factors and more than 300 enzymes that are essential for antioxidant response as well as acquired and innate immune responses [34-36]. 
Metals can exist in many different forms within the cells including as free ions. These ions are coordinately incorporated in biomolecules such as proteins or in labile association with low-molecular-weight species such as amino acids or glutathione from which the metal can be released by changes in the cellular environment [37]. They show transient changes in concentration occurring as a result of exchange between these metal-ion-binding species and labile metal ion pools within the cells [38]. A highly conserved group of proteins strictly controls the homeostasis of the essential metal ions by controlling their intake, intracellular distribution, storage, and export $[22,39,40]$. Their transport into the brain is also strictly regulated by the brain barrier system, i.e., the blood-brain and blood-cerebrospinal fluid (CSF) barriers [41]. For example, iron homeostasis is regulated by a complex network involving multiple transporter proteins including transferrin receptor 1 , divalent metal transporter 1 (DMT1), lactoferrin, melanotransferrin, and ferroportin [42]. The transport of zinc into the brain occurs via its binding with L-histidine in target sites that regulates its uptake across the brain barrier system [43]. Zinc homeostasis in the brain is also tightly regulated primarily via three families of proteins: (1) the metallothioneins, which are involved in the regulation and maintenance of intracellular zinc content [44,45]; (2) the zinc- and iron-like regulatory proteins, which are responsible for zinc uptake from extracellular fluids into both neurons and glia [46]; (3) the zinc transporters, which are associated with cellular zinc efflux [47]. Interestingly, many of these proteins regulate other metal ions transport. In the brain, zinc is also present in a free ionic form $\left(\mathrm{Zn}^{2+}\right)$ and enriched within synaptic vesicles at glutamatergic nerve terminals from where it is synaptically released during neuronal activity $[48,49]$.

Some studies have previously reported the levels at which metals are present within the brain parenchyma with various concentrations depending on the analytical methods that were used [50,51]. The literature values of concentration of various elements found by different research groups have been reviewed by Grochowski et al. [50]. In these studies, it appeared that the spectroscopic methods (e.g., paragraph 5) were the most often used for quantitative and qualitative analysis of metals in human brain samples probably due to the low limits of quantification, the ability to determine most elements of the periodic table, and the relatively short analysis time [50]. Calcium and manganese appeared to be the most abundant elements with reported concentrations as high as 50-150 $\mu \mathrm{g} / \mathrm{g}$ per dry weight in the brain of healthy adults followed by iron (20 to $100 \mu \mathrm{g} / \mathrm{g}$ ) and zinc (about $10 \mu \mathrm{g} / \mathrm{g}$ ) [50]. Copper and magnesium levels were found lower than $10 \mu \mathrm{g} / \mathrm{g}$. Increased iron and copper metal contents have also been documented in aging brain, where iron accumulates in microglia and astrocytes [52-54]. Such metal accumulations may be attributed to an increase in age-related oxidative stress as well as a progressive alteration of protein pathways that regulate their trafficking.

\subsection{Regional Heterogeneity in Brain Parenchyma}

Concentrations of metals in the brain are highly compartmentalized [51,55,56]. Accordingly, iron is present primarily in oligodendrocytes and myelin, where it is stored predominantly in its redox-inactive ferric $\left(\mathrm{Fe}^{3+}\right)$ form within ferritin [15,53]. The gray matter structures generally have higher concentrations of iron, copper, and potassium and lower concentrations of zinc than white matter, because myelin is rich in zinc, which stabilizes its structure [57-60]. The brain regions associated with motor functions contain two to three times more iron than non-motor-related regions [12]. Substantia nigra, globus pallidus, putamen, caudate nucleus, red nucleus, dentate nucleus, and locus coeruleus contain the highest concentrations of iron. Copper levels have been reported higher in the cortex and the white matter of cerebellum than in cerebrum ones [57]. They are high in the substantia nigra, locus coeruleus, dentate nucleus, and cerebellum [57,61-63]. In addition, while most iron- and copper-rich brain structures are low in zinc, the hippocampus and the amygdala have been shown to be rich in zinc metal, because these regions have numerous zincergic neurons $[58,60,64,65]$. Furthermore, high levels of manganese have been reported in the corpus pineale $[57,66]$. 


\section{Metals in Neurodegenerative Diseases and Neuroinflammation}

\subsection{Essential Metal Dyshomeostasis: A Cause or a Consequence?}

There is considerable evidence to suggest that homeostasis of metals ions play critical roles in disorders of the CNS including Alzheimer disease (AD), Parkinson's disease (PD), amyotrophic lateral sclerosis (ALS), multiple system atrophy, or prion diseases [67-70]. Alterations in the handling or increased accumulation of essential metals have been well reported to exert neurotoxicity [13]. Chronic exposure to essential metal such as manganese has been shown to result in Parkinson-like syndrome referred to as "manganism" [71]. The neurotoxicity induced by the overexposure of this metal includes disruption of mitochondrial function, disruption of neurotransmitter metabolism, alteration of iron homeostasis, and induction of oxidative stress [72-75]. In addition, metal ions such as zinc, iron, and copper have been shown to exacerbate the aggregation of $A \beta$-amyloid, $\alpha$-synuclein, prion protein, or ataxin-3 triggering neurodegeneration [1,76-78]. Iron and copper are of significant interest, because they can catalyze production of toxic reactive oxygen species (ROS) through Fenton chemistry [79-81]. In this reaction, reduced iron and copper participate in the production of hydroxyl radicals that damage proteins, DNA, and lipids through oxidative modifications. Copper plays a central role in the well-known cuprizone animal model of MS in which the copper chelator induces its neurotoxic effect through oligodendrocytes death and subsequent demyelination [14]. Metals can also bind to sulfhydryl groups (-SH) and $\mathrm{OH}, \mathrm{Cl}$ and $\mathrm{NH}_{2}$ in proteins, enzymes, coenzymes, and cell membranes inducing dysfunctions of the immune system [82]. It has also been proposed that copper levels may regulate the shift between anti-inflammatory and pro-inflammatory phenotypes in microglia via the regulation of nitric oxide levels and disruption of S-nitrosothiol signaling $[83,84]$. For instance, post-mortem analyses of amyloid plaque lesions in AD have reported an accumulation of copper, iron, and zinc compared to the normal brain [85,86]. A 339\% increase in zinc, $466 \%$ increase in copper, and $177 \%$ increase in iron have been found in the plaques in comparison to the healthy subjects [87]. In these lesions, copper-amyloid complexes are expected to catalyze the production of ROS involved in neuronal death $[88,89]$.

\subsection{Xenobiotic and Essential Metals Interplay}

Additionally, environmental xenobiotic metals such as mercury, lead, aluminum, arsenic, and cadmium are other candidate that may enter the organism and interfere with biological chemistry in the brain. These xenobiotic compounds have been detected in the normal brain with aluminum levels as high as $100 \mu \mathrm{g} / \mathrm{g}$ [90]. New applications and manufacturing processes increasingly expose humans to a number of metals to which they have not been exposed to in the past. Common sources of the metals are mining, burning of fossil fuels, tailings, industrial waste, agricultural runoff, paints, treated timber, aging water supply infrastructure, vehicle emission, lead-acid batteries, electronic components, fertilizers, and microplastics. They may be found in organic or inorganic chemical compounds, such as solvents and cytotoxic substances (e.g., pesticides, cigarette smoke, diesel exhaust particles) [91]. Moreover, environmental and occupational exposure to one metal is likely to be accompanied by exposure to other metals as well, and it is expected that interactions between different metals may occur in populations exposed to mixtures of metals with other chemicals. The main route of human exposure to these metals include food, drinking water, metal-containing drug ingestion, inhalation, and dermal contact. These metals generally have long biological half-life due to the lack of bodily recognition system. The levels of these toxic metals in the blood have been associated with polymorphisms in metal transporter genes, thus providing evidence that subsets of individuals are more susceptible to the toxic effects of some metals [92].

Xenobiotic metals interfere with the biological activity of proteins through diverse mechanisms. They may (1) displace essential metal ions and compete for their binding sites; (2) bind to free thiol $(-\mathrm{SH})$ and selenol groups of proteins; (3) catalyze oxidation of amino acid side chains; (4) interfere with the folding of protein into 3D structure; (5) prevent their refolding [93]. These interferences affect 
metal transporters and other proteins and promote energy failure due to mitochondrial dysfunction, protein damage/aggregation, and metabolic alterations that challenge neuroglial function and trigger excitotoxic and inflammatory processes [94]. Oxidative stress caused by ROS is also a well-known mechanism of xenobiotic metal-induced damages [95,96]. Moreover, ROS leads to imbalance in homeostasis between antioxidant and pro-oxidant molecules and results in oxidative stress-related damage to cellular components such as proteins, DNA, and lipids [96].

For example, the most abundant form of mercury in the human body, known as organic methylmercury, enters the organism through pelagic species (fish and shellfish) consumption. This metal comes from inorganic mercury methylated by microorganisms from aquatic environment, and it is known to present high affinity for sulfhydryl (thiol) and selenohydryl (selenol) groups in proteins and to cross the blood-brain barrier by binding onto thiol groups of proteins; it can also bind to lone cysteine, mimicking the structure of methionine allowing for the uptake by amino acid transporters [97,98]. Several studies have established that this metal leads to depletion of intracellular antioxidants such as glutathione (GSH) and inhibition of several enzymes [99]. Aluminum is known to amplify catalytic pro-oxidant reactions involving essential metals [100-102]. This metal exposure causes the disruption of iron homeostasis leading to iron overload and oxidative stress [103,104]. This metal may also decrease ferritin synthesis and increase the expression of transferrin receptors, thereby increasing free iron levels in the cell resulting in an increase in oxidative damage via the Fenton reaction [105]. Aluminum has been shown to bind to ferritin and compete with iron for its binding to the transporter fransferrin and to induce oxidative damage, which can lead to neurodegeneration in the animal model $[106,107]$. Aluminum has also been shown to influence calcium homeostasis and calcium-dependent processes in the brain such as programmed cell death in astrocytes [108]. Animal studies have also shown that aluminum exposure affects permeability of the blood-brain barrier, cholinergic activity, signal transduction pathways, and impair neuronal glutamate nitric oxide-cyclic GMP pathway [109,110]. Aluminum exposure also decreases reduced gluthatione (GSH) levels and the activities of catalase, superoxide dismutase, glutathione peroxidase (GPx), and glutathione reductase and increases the levels of nitric oxide (NO) [111,112]. Thus, oxidative stress and subsequent mitochondrial dysfunction constitute the major vehicle underpinning aluminum-induced neurotoxicity (reviewed by Kumar et al. [113]). Aluminum can also activate microglia leading to secretion of TNF-alpha, IL-6, and cytokine-inducible nitric oxide synthase (iNOS or NOS-2) and the induction of proinflammatory cytokines [114]. Interestingly, high concentrations of this metal have been reported in the brain of patients with $\mathrm{AD} \mathrm{[115],} \mathrm{and} \mathrm{recently,} \mathrm{a} \mathrm{meta-analysis} \mathrm{has} \mathrm{shown} \mathrm{that} \mathrm{chronic} \mathrm{exposure}$ to it increases the risk of the disease [116]. Lead, another xenobiotic metal, has proved acute toxicity by interfering with the metabolism of essential metals, particularly that of calcium, iron, copper, and zinc $[117,118]$. Through its binding to thiol groups of both reduced glutathione (GSH) and oxidized glutathione (GSSH), this metal can also disturb the GSH/GSSH balance and renders cells more prone to oxidative damage [119]. Cadmium is another element with considerable toxicity for humans that may be taken up in rather high concentrations via edible parts of plants [120]. Cadmium accumulates with age in metallothioneins, which are involved in zinc and copper metabolism, as mentioned above [120-122]. Interestingly, mercury, lead, and cadmium metals have also been shown to exacerbate autoimmunity in the animal model. Similar to all xenobiotics, these metals may have a direct or indirect immunomodulatory effect on subpopulations, such as Thelper type 1 (Th1), type 2 (Th2), and type 17 (Th17) cells and regulatory $\mathrm{T}$ (Treg) cells, thus disturbing the balance of otherwise finely tuned immune reactions [123-128].

\section{Metals Imbalance in Multiple Sclerosis Patients}

\subsection{Metals in the Blood or Serum}

The deregulation of metal homeostasis as a cause of MS is still a matter of debate [129-132]. Literature data concerning metal alterations in MS patients are partly contradictory and may depend on 
the biological specimens used for analysis (such as blood, serum, hair, urine, CSF, or post-mortem tissues from autopsy) making comparisons between studies of limited values. Several studies using atomic absorption spectrophotometry, the colorimetric method, or neutron activation analysis have reported altered metal levels in blood or serum from MS patients, such as decreased levels of zinc [132-134], increased levels of copper [135,136], increased levels of arsenic and lead [137,138], and increased levels of mercury [139] compared to healthy control groups.

Inductively coupled plasma mass spectrometry (ICP-MS) technology has also been used in some studies to analyze simultaneously several metals in MS patients. A chemical element profile has been reported by Alimonti et al. using ICP atomic emission spectrometry and ICP-MS in a series of sixty relapsing-remitting and secondary progressive patients [140]. In this study, the authors found a complex metal imbalance, notably low iron and zinc levels and high levels of calcium, zirconium, cadmium, tungsten, antimony, silicon, and nickel elements in serum of MS patients compared to healthy controls. They found that this imbalance was associated with an increase in serum oxidative status and with a decrease in serum anti-oxidant capacity [140]. In 2017, Janghorbani et al. reported in a series of 55 MS patients a lower concentration for calcium, iron, potassium, sulfur, sodium, phosphorus, and zinc as well as increased concentrations of copper and silicon in the blood of MS patients compared to healthy individuals [141]. Recently, a study designed by De Oliveira et al. investigating several metal elements by ICP-MS technology in MS patients has reported lower blood concentrations of beryllium, copper, chromium, cobalt, nickel, magnesium, and iron metals and higher concentrations of lead compared to healthy subjects [142]. Another recent study conducted by Siotto et al. has also reported in the peripheral blood of a series of 60 relapsing-remitting MS patients' higher copper levels, decreased antioxidant capacity, and increased oxidative status compared to healthy controls [143]. Interestingly, these authors also found that iron levels were higher in the group of untreated MS patients compared to controls and patients receiving interferon-beta treatment suggesting a role of the therapy in oxidative stress related to iron metabolism [143]. Overall, these studies suggest that a set of different metals related to systemic oxidative status is linked to MS disease progression.

\subsection{Iron in the Central Nervous System}

Intratissue metal contents in the brain of MS patients have only been published using post mortem specimens. Alterations in iron content and distribution in these tissues are complex and well documented. These iron-related findings have originally been established on brain tissue sections using histochemical methods by Hametner et al. [19]. Studies have shown a loss of iron in most active and inactive lesions compared to the surrounding normal appearing white matter (NAWM) $[19,144,145]$. Iron levels have been shown to decrease in the NAWM of MS patients compared to controls with increasing disease duration, presumably due to the destruction of iron-loaded oligodendrocytes $[19,144]$. Compared to age-matched control subjects, increased amounts of iron have been observed in the basal ganglia and motor cortex of MS patients [146-148]. Active lesions may contain variable numbers of iron-loaded macrophages and a low content in astrocytes $[19,144,149]$. Reactive astrocytes organized in large astrogliotic areas in a subset of smoldering and inactive plaques accumulate iron as ferrihydrite in ferritin in the brain of patients [144]. In addition, at the edges of slowly expanding and some inactive lesions, iron accumulation has been described within microglia/macrophages showing a pro-inflammatory immunophenotype (CD86 and p22phox) [19,149,150]. These iron-related changes in the MS brain are likely to depend on the source of iron (heme or non-heme iron), the cell-type-specific expression patterns of iron-transport molecules, and their alterations in the demyelinating and neurodegenerative process [26]. It appears clear that microglia play a critical role in the maintenance of brain iron homeostasis; however, more studies are needed to elucidate the mechanisms and conditions in which iron cycling by microglia contributes to or is protective against neural disorders. Interestingly, a study by Magliozzi et al. regarding proteomic technology has correlated intrathecal deregulation of iron homeostasis pathway to cortical damage at early disease stage in MS patients [151]. Moreover, brain iron content evaluated by quantitative MRI in deep gray matter structures has been correlated 
with levels of disability in MS patients [152]. In addition, iron content in deep gray matter in progressive MS patients have been associated with the presence of genetic variants associated with iron regulation and metabolism [153]. Overall, these studies highlight the well-established imbalance of iron metal in the brain of MS patients possibly due to deregulated trafficking of this metal.

\subsection{Other Metals (Magnesium, Copper, Manganese, Zinc, Aluminum) in the Central Nervous System}

Alterations in other metal contents in brain of MS patients are far less documented. Yasui et al. reported lower levels of magnesium in MS patients compared to the control group [154]. Studies have reported increased levels of copper and decreased levels of manganese in the CSF of MS patients compared to healthy control groups $[135,155]$. Popescu et al. found decreased zinc levels in most white matter lesions of MS patients [61]. In a meta-analysis, Bredholt et al. also reported higher levels of zinc in CSF of MS patients compared to healthy controls [156]. It is interesting to note that zinc metal has been linked to the regulation of matrix metalloproteinase (MMP) activity by a mechanism that was named "cysteine switch" [157]. Disruption of interaction between zinc and cysteine residue in the metal binding-site containing catalytic domain is known to induce the full activation of these enzymes. Interestingly, increased expression of two zinc-regulating metallothionein isoforms I+II (MT-I+II) has been previously shown in astrocytes and activated macrophages/microglia [158] as well as overexpression of matrix metalloproteinases MMP-2, 7, and 9 in astrocytes, endothelial cells, lymphocytes, and macrophages, especially around blood vessels within MS lesions [159-164]. Otherwise, high contents and questionable tissue deposits of aluminum have been reported in both white and grey matter of brain parenchyma from MS patients [165] and recently significant higher contents of this metal have been evidenced in these tissues compared to the control group [166]. Thus, it appears that iron and probably zinc metals are linked to MS pathophysiology, although the description of their precise role in this process requires further studies.

A schematic description of some putative xenobiotic-induced metal imbalance involved in physiopathological process in CNS of MS patients is depicted in Figure 1.

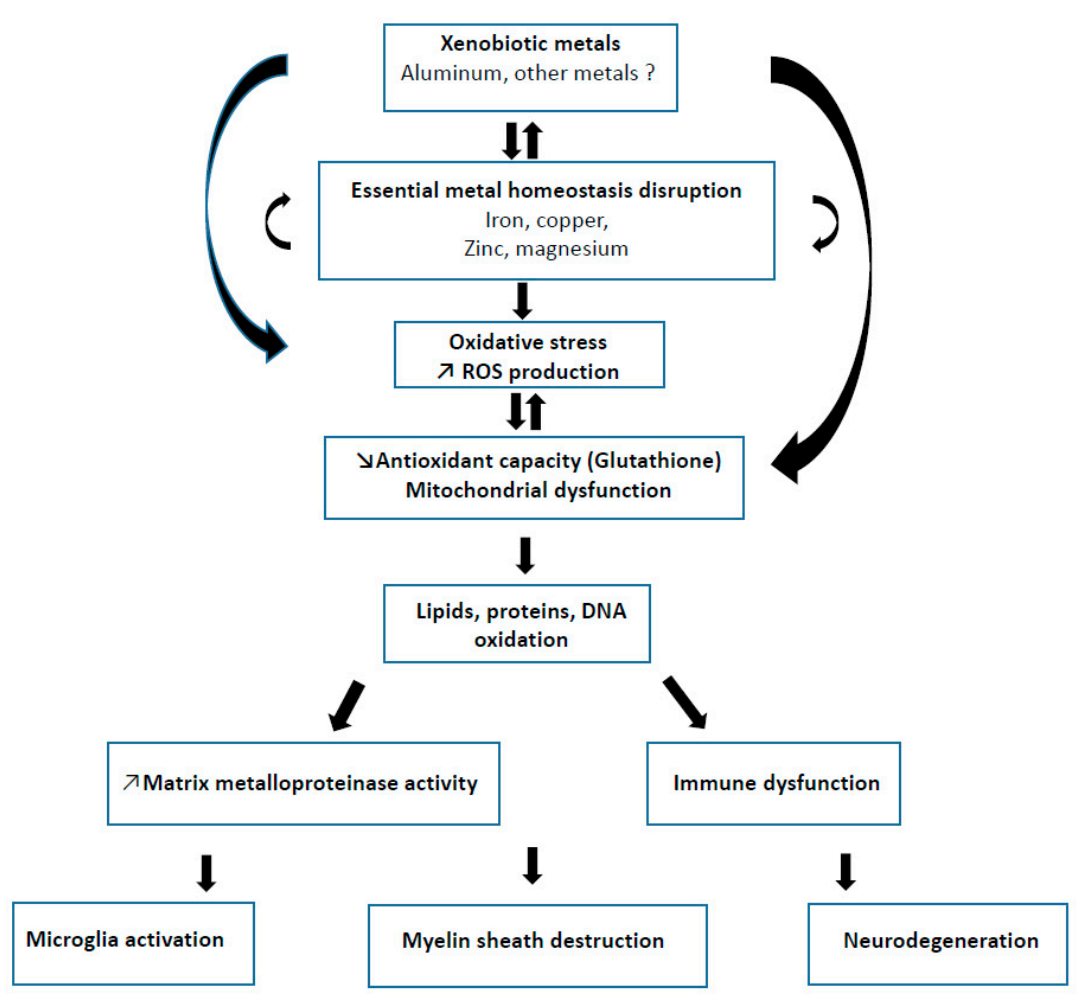

Figure 1. Schematic description of some putative xenobiotic-induced metal imbalance involved in physiopathological process in CNS of MS patients. 


\section{Elemental Imaging for Understanding the Complexity of Metal Biochemistry?}

The chemical elements essential for the normal brain metabolism and functioning such as calcium, copper, zinc, or iron are known to be interdependent. For example, due to their physicochemical nature, zinc and copper can compete for the binding sites of the same transporters and metal-binding proteins resulting in an antagonistic relationship, where low levels of zinc increase copper levels and vice versa [167]. As previously mentioned, there are elements such as aluminum, which can modify the transport and uptake into cells of essential metal ions such as iron [100,101]. Due to these interactions, the increase or the loss of one metal can lead to the establishment of a completely new metal profile affecting many others [168]. Most investigations on metallic elements in MS disease have evidenced accumulation or depletion of some elements (more evident for iron and zinc) in different biological samples or post-mortem tissue specimens. However, these studies are still controversial, because most of them have considered a small number of elements and are hampered by methodological limitations in terms of analytical quality, such as reduced number of samples and the different techniques applied.

Understanding the complexity of metallochemistry in the living brain is critical for designing appropriate therapeutic interventions. The inventory of metals and their species, including metalloproteins and metalloenzymes, in biological samples is termed as the metallome and its analysis as metallomics [169]. The sensitivity and specificity achievable with modern technologies allows the investigation of metal toxicity such as environmental exposure to xenobiotic metals [170-173]. Moreover, these methods enable the imaging of metal species and metal-containing compounds in biological samples. In situ visualization of metals in cells and tissues may play a major part in describing and in depth understanding of the metal chemistry. The characterization of metal distribution (imaging or mapping) in biological tissues has been of interest for a long time and technologies are now enabling such detection, each one achieving different spatial resolution, element selectivity, detection limit, and analytical depth [174-177]. Most of the current imaging techniques rely on methods that employ metal-selective probes/chemical sensors, light/lasers, electrons, $\mathrm{X}$-ray, energetic particles, or mass spectrometric detection to measure characteristic radiation $[37,176,177]$. These techniques can be broadly divided into three groups: spectroscopy imaging (MRI, Fourier transform infrared imaging, Raman imaging, confocal laser scanning microscopy, super resolution microscopy, $\mathrm{X}$-ray microscopy, synchrotron $\mathrm{X}$-ray fluorescence microscopy, X-ray absorption spectroscopy, coherent diffractive imaging, positron emission tomography, laser-induced breakdown spectroscopy, mass spectrometry imaging (ICP-MS, secondary ion mass spectrometry, matrix-assisted laser desorption/ionization mass spectrometry imaging), and particle beam microscopy (electron microscopy, particle-induced X-ray emission). MRI is an established biomedical imaging technique of iron enabling the analysis of the anatomy and physiological processes of the brain. It provides high-resolution tomographic images with excellent tissue contrast; its spatial resolution is at the organ level but does not reach the cellular level. Some of these imaging techniques have previously been applied to study metals within the CNS in ex vivo brain tissue sections $[67,178]$. These technologies supported the studies of the normal brain and of disease-mediated changes in the storage and metabolism of metal, which may occur in specific intracellular compartments [179] or as widespread accumulation in multiple regions of the brain [180]. These imaging techniques have previously reported altered metal composition in brain tissue sections of patients with neurodegenerative diseases, such as AD, PD, and ALS [70,178,181,182] but not of MS patients, to our knowledge.

\section{Conclusions and Perspectives}

Metals are essential for human health and brain function. Alterations in their content or distribution are expected to exert neurotoxicity. Both alterations in the chemistry of essential metals and environmental exposure to xenobiotic metals can have silent chronic effects leading to neurodegeneration and neurological dysfunction. The restoration of metal homeostasis by using specific chelators has been considered in the past as a key pharmacological target in neurodegenerative diseases $[23,183,184]$. However, the complexity of the whole metal homeostasis in the brain has been largely unexplored, and only few clinical trials evaluating safety and therapeutic value of iron chelation therapies have been 
performed in the past in MS patients. Thus, further investigations are needed to describe broader metal biochemistry abnormalities in the brain and identify potential new therapeutic strategies in these patients. There is an increasing need for integrating safe and non-invasive analytical tools and imaging techniques to afford a complete picture of the metallome, including in vivo information on metal accumulation or depletion and distribution in the brain of MS patients for clinical purpose.

Our review should be considered as a prerequisite before undertaking in-depth complex transdisciplinary analytical studies on metals in the brain of MS patients. At a clinical level, such studies may provide in the future new perspectives for identification of metals classified as a risk factor or possible cause of the disease, ameliorating diagnosis, appreciating severity, and anticipating relapses as well as providing specific metal profiles indicative for a clinical response to innovative metal-targeted therapeutics. The targeting of one (or several) metal requires caution, by evaluating its specificity and its potential toxicity. The requirement for a metal chelator needs to be carefully considered, because high-affinity chelators may remove metals from "biological circulation" but may also trip metals from normal endogenous protein pathways. In contrast, moderate affinity chelators may have less impact on normal cellular processes. In addition, careful design may result in compounds that can effectively re-distribute metals from areas of excess to areas of deficiency, thereby reducing "toxic" events and also ensuring that physiological metal-dependent pathways remain functional. Development of such compounds referred to as "ionophores", "modulators", "chaperones", or "metal protein attenuating compounds" must be encouraged.

Author Contributions: Conceptualization, J.-P.D. and S.D.-J.; writing-original draft preparation, J.-P.D.; writing-review and editing, S.D.-J. All authors have read and agreed to the published version of the manuscript.

Funding: This review article received no external funding.

Conflicts of Interest: The authors declare no conflict of interest.

\section{References}

1. Madsen, E.; Gitlin, J.D. Copper and Iron Disorders of the Brain. Annu. Rev. Neurosci. Juill. 2007, 30, 317-337. [CrossRef]

2. Zecca, L.; Youdim, M.B.H.; Riederer, P.; Connor, J.R.; Crichton, R.R. Iron, brain ageing and neurodegenerative disorders. Nat. Rev. Neurosci. 2004, 5, 863-873. [CrossRef] [PubMed]

3. Que, E.L.; Domaille, D.W.; Chang, C.J. Metals in Neurobiology: Probing Their Chemistry and Biology with Molecular Imaging. Chem. Rev. 2008, 108, 1517-1549. [CrossRef]

4. Prüss-Üstün, A.; Wolf, J.; Corvalán, C.; Bos, R.; Neira, M. Preventing Disease Through Healthy Environments: A Global Assessment of The Burden of Disease from Environmental Risks, 2nd ed.; World Health Organization: Geneva, Switzerland, 2016; p. 147.

5. Earl, C.; Chantry, A.; Mohammad, N.; Glynn, P. Zinc Ions Stabilise the Association of Basic Protein with Brain Myelin Membranes. J. Neurochem. 1988, 51, 718-724. [CrossRef]

6. Todorich, B.; Pasquini, J.M.; Garcia, C.I.; Paez, P.M.; Connor, J.R. Oligodendrocytes and myelination: The role of iron. Glia 2009, 57, 467-478. [CrossRef] [PubMed]

7. Tsang, D.; Tsang, Y.S.; Ho, W.K.K.; Wong, R.N.S. Myelin basic protein is a zinc-binding protein in brain: Possible role in myelin compaction. Neurochem. Res. 1997, 22, 811-819. [CrossRef]

8. Kurien, B.T.; Scofield, R.H. Autoimmunity and oxidatively modified autoantigens. Autoimmun. Rev. 2008, 7, 567-573. [CrossRef]

9. Fontenot, A.P.; Falta, M.T.; Kappler, J.W.; Dai, S.; McKee, A.S. Beryllium-Induced Hypersensitivity: Genetic Susceptibility and Neoantigen Generation. J. Immunol. 2015, 196, 22-27. [CrossRef] [PubMed]

10. Dexter, D.T;; Carayon, A.; Javoy-Agid, F.; Agid, Y.; Wells, F.R.; Daniel, S.E.; Lees, A.J.; Jenner, P.; Marsden, C.D. Alterations in the levels of iron, ferritin and other trace metals in parkinson's disease and other neurodegenerative diseases affecting the basal ganglia. Brain 1991, 114, 1953-1975. [CrossRef] [PubMed]

11. Dexter, D.T.; Sian, J.; Jenner, P.; Marsden, C.D. Implications of alterations in trace element levels in brain in Parkinson's disease and other neurological disorders affecting the basal ganglia. Adv. Neurol. 1993, 60, 273-281. [PubMed] 
12. Dexter, D.T.; Wells, F.R.; Lee, A.J.; Agid, F.; Agid, Y.; Jenner, P.; Marsden, C.D. Increased Nigral Iron Content and Alterations in Other Metal Ions Occurring in Brain in Parkinson's Disease. J. Neurochem. 1989, 52, 1830-1836. [CrossRef] [PubMed]

13. Garza-Lombó, C.; Posadas, Y.; Quintanar, L.; Gonsebatt, M.E.; Franco, R. Neurotoxicity Linked to Dysfunctional Metal Ion Homeostasis and Xenobiotic Metal Exposure: Redox Signaling and Oxidative Stress. Antioxidants Redox Signal. 2018, 28, 1669-1703. [CrossRef] [PubMed]

14. Bénardais, K.; Kotsiari, A.; Škuljec, J.; Koutsoudaki, P.N.; Gudi, V.; Singh, V.; Vulinovic, F.; Skripuletz, T.; Stangel, M. Cuprizone [Bis(Cyclohexylidenehydrazide)] is Selectively Toxic for Mature Oligodendrocytes. Neurotox. Res. 2013, 24, 244-250. [CrossRef] [PubMed]

15. Bates, M.N. Health effects of dental amalgam exposure: A retrospective cohort study. Int. J. Epidemiol. 2004, 33, 894-902. [CrossRef]

16. Aminzadeh, K.K.; Etminan, M. Dental Amalgam and Multiple Sclerosis: A Systematic Review and Meta-Analysis. J. Public Health Dent. 2007, 67, 64-66. [CrossRef] [PubMed]

17. Exley, C.; Mamutse, G.; Korchazhkina, O.; Pye, E.; Strekopytov, S.; Polwart, A.; Hawkins, C. Elevated urinary excretion of aluminium and iron in multiple sclerosis. Mult. Scler. J. 2006, 12, 533-540. [CrossRef]

18. Jones, K.; Linhart, C.; Hawkins, C.; Exley, C. Urinary Excretion of Aluminium and Silicon in Secondary Progressive Multiple Sclerosis. EBioMedicine 2017, 26, 60-67. [CrossRef]

19. Hametner, S.; Wimmer, I.; Haider, L.; Pfeifenbring, S.; Brück, W.; Lassmann, H. Iron and neurodegeneration in the multiple sclerosis brain: Iron in the MS Brain. Ann. Neurol. 2013, 74, 848-861. [CrossRef]

20. LeVine, S.M.; Lynch, S.G.; Ou, C.-N.; Wulser, M.J.; Tam, E.; Boo, N. Ferritin, transferrin and iron concentrations in the cerebrospinal fluid of multiple sclerosis patients. Brain Res. 1999, 821, 511-515. [CrossRef]

21. Ristori, G.; Brescianini, S.; Pino, A.; Visconti, A.; Vittori, D.; Coarelli, G.; Cotichini, R.; Bocca, B.; Forte, G.; Pozzilli, C.; et al. Serum elements and oxidative status in clinically isolated syndromes: Imbalance and predictivity. Neurology 2011, 76, 549-555. [CrossRef]

22. Chang, C.J. Searching for harmony in transition-metal signaling. Nat. Chem. Biol. 2015, 11, 744-747. [CrossRef] [PubMed]

23. Barnham, K.J.; Bush, A.I. Biological metals and metal-targeting compounds in major neurodegenerative diseases. Chem. Soc. Rev. 2014, 43, 6727-6749. [CrossRef] [PubMed]

24. Ortiz, E.; Pasquini, J.M.; Thompson, K.; Felt, B.; Butkus, G.; Beard, J.; Connor, J.R. Effect of manipulation of iron storage, transport, or availability on myelin composition and brain iron content in three different animal models. J. Neurosci. Res. 2004, 77, 681-689. [CrossRef] [PubMed]

25. Kursula, P.; Meriläinen, G.; Lehto, V.P.; Heape, A.M. The small myelin-associated glycoprotein is a zinc-binding protein. J. Neurochem. 1999, 73, 2110-2118. [PubMed]

26. Hametner, S.; Dal Bianco, A.; Trattnig, S.; Lassmann, H. Iron related changes in MS lesions and their validity to characterize MS lesion types and dynamics with Ultra-high field magnetic resonance imaging. Brain Pathol. 2018, 28, 743-749. [CrossRef]

27. Connor, J.R.; Menzies, S.L. Cellular management of iron in the brain. J. Neurol. Sci. 1995, 134, 33-44. [CrossRef]

28. Gaier, E.D.; Eipper, B.A.; Mains, R.E. Copper signaling in the mammalian nervous system: Synaptic effects. J. Neurosci. Res. 2013, 91, 2-19. [CrossRef]

29. Lutsenko, S.; Bhattacharjee, A.; Hubbard, A.L. Copper handling machinery of the brain. Metallomics 2010, 2, 596. [CrossRef]

30. Opazo, C.M.; Greenough, M.A.; Bush, A.I. Copper: From neurotransmission to neuroproteostasis. Front. Aging Neurosci. 2014, 6, 143. [CrossRef]

31. Aschner, M. Manganese Homeostasis in the CNS. Environ. Res. 1999, 80, 105-109. [CrossRef]

32. Kirkley, K.S.; Popichak, K.A.; Afzali, M.F.; Legare, M.E.; Tjalkens, R.B. Microglia amplify inflammatory activation of astrocytes in manganese neurotoxicity. J. Neuroinflam. 2017, 14, 99. [CrossRef] [PubMed]

33. Tjalkens, R.B.; Popichak, K.A.; Kirkley, K.A. Inflammatory Activation of Microglia and Astrocytes in Manganese Neurotoxicity. Adv. Neurobiol. 2017, 18, 159-181. [PubMed]

34. Takeda, A. Movement of zinc and its functional significance in the brain. Brain Res. Rev. 2000, 34, 137-148. [CrossRef]

35. Ibs, K.-H.; Rink, L. Zinc-Altered Immune function. J. Nutr. 2003, 133, 1452S-1456S. [CrossRef] 
36. Mohammadi, E.; Qujeq, D.; Taheri, H.; Hajian-Tilaki, K. Evaluation of Serum Trace Element Levels and Superoxide Dismutase Activity in Patients with Inflammatory Bowel Disease: Translating Basic Research into Clinical Application. Biol. Trace Element Res. 2017, 177, 235-240. [CrossRef]

37. Dean, K.M.; Qin, Y.; Palmer, A.E. Visualizing metal ions in cells: An overview of analytical techniques, approaches, and probes. Biochim. Biophys. Acta (BBA) Bioenerg. 2012, 1823, 1406-1415. [CrossRef]

38. Krężel, A.; Maret, W. The biological inorganic chemistry of zinc ions. Arch. Biochem. Biophys. 2016, 611, 3-19. [CrossRef]

39. Outten, F.W.; Twining, B.S.; Begley, T.P. Metal Homeostasis. In Wiley Encyclopedia of Chemical Biology; Wiley: Hoboken, NJ, USA, 2008; p. 324.

40. Martinez-Finley, E.J.; Chakraborty, S.; Fretham, S.J.B.; Aschner, M. Cellular transport and homeostasis of essential and nonessential metals. Metallomics 2012, 4, 593. [CrossRef]

41. Skjørringe, T.; Møller, L.B.; Moos, T. Impairment of Interrelated Iron- and Copper Homeostatic Mechanisms in Brain Contributes to the Pathogenesis of Neurodegenerative Disorders. Front. Pharmacol. 2012, 3, 169. [CrossRef]

42. Liu, J.-L.; Fan, Y.-G.; Yang, Z.-S.; Wang, Z.-Y.; Guo, C. Iron and Alzheimer's Disease: From Pathogenesis to Therapeutic Implications. Front. Neurosci. 2018, 12, 632. [CrossRef]

43. Takeda, A. Zinc homeostasis and functions in the brain. BioMetals 2001, 14, 343-351. [CrossRef] [PubMed]

44. Mocchegiani, E.; Giacconi, R.; Cipriano, C.; Muzzioli, M.; Fattoretti, P.; Bertoni-Freddari, C.; Isani, G.; Zambenedetti, P.; Zatta, P. Zinc-bound metallothioneins as potential biological markers of ageing. Brain Res. Bull. 2001, 55, 147-153. [CrossRef]

45. Vašák, M.; Meloni, G. Mammalian Metallothionein-3: New Functional and Structural Insights. Int. J. Mol. Sci. 2017, 18, 1117. [CrossRef] [PubMed]

46. Liuzzi, J.P.; Cousins, R.J. Mammalian zinc transporters. Annu. Rev. Nutr. 2004, 24, 151-172. [CrossRef] [PubMed]

47. Kambe, T.; Tsuji, T.; Hashimoto, A.; Itsumura, N. The Physiological, Biochemical, and Molecular Roles of Zinc Transporters in Zinc Homeostasis and Metabolism. Physiol. Rev. 2015, 95, 749-784. [CrossRef] [PubMed]

48. Paoletti, P.; Vergnano, A.M.; Barbour, B.; Casado, M. Zinc at glutamatergic synapses. Neuroscience 2009, 158, 126-136. [CrossRef]

49. Radford, R.J.; Lippard, S.J. Chelators for investigating zinc metalloneurochemistry. Curr. Opin. Chem. Biol. 2013, 17, 129-136. [CrossRef]

50. Grochowski, C.; Blicharska, E.; Krukow, P.; Jonak, K.; Maciejewski, M.; Szczepanek, D.; Jonak, K.; Flieger, J.; Maciejewski, R. Analysis of Trace Elements in Human Brain: Its Aim, Methods, and Concentration Levels. Front. Chem. 2019, 7, 115. [CrossRef]

51. Krebs, N.; Langkammer, C.; Goessler, W.; Ropele, S.; Fazekas, F.; Yen, K.; Scheurer, E. Assessment of trace elements in human brain using inductively coupled plasma mass spectrometry. J. Trace Elem. Med. Biol. 2014, 28, 1-7. [CrossRef]

52. Markesbery, W.R.; Ehmann, W.D.; Alauddin, M.; Hossain, T.I.M. Brain trace element concentrations in aging. Neurobiol. Aging 1984, 5, 19-28. [CrossRef]

53. Connor, J.R.; Menzies, S.L.; Martin, S.S.; Mufson, E.J. Cellular distribution of transferrin, ferritin, and iron in normal and aged human brains. J. Neurosci. Res. 1990, 27, 595-611. [CrossRef] [PubMed]

54. Dringen, R.; Bishop, G.M.; Koeppe, M.; Dang, T.N.; Robinson, S.R. The Pivotal Role of Astrocytes in the Metabolism of Iron in the Brain. Neurochem. Res. 2007, 32, 1884-1890. [CrossRef] [PubMed]

55. Harrison, W.W.; Netsky, M.G.; Brown, M.D. Trace elements in human brain: Copper, zinc, iron, and magnesium. Clin. Chim. Acta 1968, 21, 55-60. [CrossRef]

56. Hare, D.J.; Lee, J.K.; Beavis, A.D.; van Gramberg, A.; George, J.; Adlard, P.A.; Finkelstein, D.I.; Doble, P.A. Three-Dimensional Atlas of Iron, Copper, and Zinc in the Mouse Cerebrum and Brainstem. Anal. Chem. 2012, 84, 3990-3997. [CrossRef] [PubMed]

57. Duflou, H.; Maenhaut, W.; De Reuck, J. Regional distribution of potassium, calcium, and six trace elements in normal human brain. Neurochem. Res. 1989, 14, 1099-1112. [CrossRef]

58. Gh Popescu, B.F.; George, M.J.; Bergmann, U.; Garachtchenko, A.V.; Kelly, M.E.; McCrea, R.P.E.; Lüning, K.; Devon, R.M.; George, G.N.; Hanson, A.D.; et al. Mapping metals in Parkinson's and normal brain using rapid-scanning x-ray fluorescence. Phys. Med. Biol. 2009, 54, 651-663. [CrossRef] 
59. Dobrowolska, J.; Dehnhardt, M.; Matusch, A.; Zoriy, M.; Palomero-Gallagher, N.; Koscielniak, P.; Zilles, K.; Becker, J.S. Quantitative imaging of zinc, copper and lead in three distinct regions of the human brain by laser ablation inductively coupled plasma mass spectrometry. Talanta 2008, 74, 717-723. [CrossRef]

60. Popescu, B.F.G.H.; Robinson, C.A.; Chapman, L.D.; Nichol, H. Synchrotron X-ray Fluorescence Reveals Abnormal Metal Distributions in Brain and Spinal Cord in Spinocerebellar Ataxia: A Case Report. Cerebellum 2009, 8, 340-351. [CrossRef]

61. Popescu, B.F.G.H.; Robinson, C.A.; Rajput, A.; Rajput, A.H.; Harder, S.L.; Nichol, H. Iron, Copper, and Zinc Distribution of the Cerebellum. Cerebellum 2009, 8, 74-79. [CrossRef]

62. Goldberg, W.J.; Allen, N. Determination of $\mathrm{Cu}, \mathrm{Mn}, \mathrm{Fe}$, and $\mathrm{Ca}$ in six regions of normal human brain, by atomic absorption spectroscopy. Clin. Chem. 1981, 27, 562-564. [CrossRef]

63. Warren, P.J.; Earl, C.J.; Thompson, R.H.S. The distribution of copper in human brain. Brain 1960, 83, 709-717. [CrossRef] [PubMed]

64. Cuajungco, M.P.; Lees, G.J. Zinc Metabolism in the Brain: Relevance to Human Neurodegenerative Disorders. Neurobiol. Dis. 1997, 4, 137-169. [CrossRef] [PubMed]

65. Mocchegiani, E.; Bertoni-Freddari, C.; Marcellini, F.; Malavolta, M. Brain, aging and neurodegeneration: Role of zinc ion availability. Prog. Neurobiol. 2005, 75, 367-390. [CrossRef] [PubMed]

66. Martinez-Finley, E.J.; Gavin, C.E.; Aschner, M.; Gunter, T.E. Manganese neurotoxicity and the role of reactive oxygen species. Free Radic. Biol. Med. 2013, 62, 65-75. [CrossRef]

67. Davies, K.M.; Bohic, S.; Carmona, A.; Ortega, R.; Cottam, V.; Hare, D.J.; Finberg, J.P.; Reyes, S.; Halliday, G.M.; Mercer, J.F.; et al. Copper pathology in vulnerable brain regions in Parkinson's disease. Neurobiol. Aging 2014, 35, 858-866. [CrossRef]

68. Hung, Y.H.; Bush, A.I.; Cherny, R.A. Copper in the brain and Alzheimer's disease. JBIC J. Biol. Inorg. Chem. 2010, 15, 61-76. [CrossRef]

69. Koeppen, A.H.; Ramirez, R.L.; Yu, D.; Collins, S.E.; Qian, J.; Parsons, P.J.; Yang, K.X.; Chen, Z.; Mazurkiewicz, J.E.; Feustel, P.J. Friedreich's Ataxia Causes Redistribution of Iron, Copper, and Zinc in the Dentate Nucleus. Cerebellum 2012, 11, 845-860. [CrossRef]

70. Bourassa, M.W.; Miller, L.M. Metal imaging in neurodegenerative diseases. Metallomics 2012, 4, 721. [CrossRef]

71. Kwakye, G.; Paoliello, M.; Mukhopadhyay, S.; Bowman, A.; Aschner, M. Manganese-Induced Parkinsonism and Parkinson's Disease: Shared and Distinguishable Features. Int. J. Environ. Res. Public Health 2015, 12, 7519-7540. [CrossRef]

72. Chtourou, Y.; Trabelsi, K.; Fetoui, H.; Mkannez, G.; Kallel, H.; Zeghal, N. Manganese Induces Oxidative Stress, Redox State Unbalance and Disrupts Membrane Bound ATPases on Murine Neuroblastoma Cells In Vitro: Protective Role of Silymarin. Neurochem. Res. 2011, 36, 1546-1557. [CrossRef]

73. Kwik-Uribe, C.; Smith, D.R. Temporal responses in the disruption of iron regulation by manganese. J. Neurosci. Res. 2006, 83, 1601-1610. [CrossRef] [PubMed]

74. Fitsanakis, V.A.; Au, C.; Erikson, K.M.; Aschner, M. The effects of manganese on glutamate, dopamine and $\gamma$-aminobutyric acid regulation. Neurochem. Int. 2006, 48, 426-433. [CrossRef] [PubMed]

75. Tamm, C.; Sabri, F.; Ceccatelli, S. Mitochondrial-Mediated Apoptosis in Neural Stem Cells Exposed to Manganese. Toxicol. Sci. 2008, 101, 310-320. [CrossRef] [PubMed]

76. Ricchelli, F.; Fusi, P.; Tortora, P.; Valtorta, M.; Riva, M.; Tognon, G.; Chieregato, K.; Bolognin, S.; Zatta, P. Destabilization of non-pathological variants of ataxin-3 by metal ions results in aggregation/fibrillogenesis. Int. J. Biochem. Cell Biol. 2007, 39, 966-977. [CrossRef]

77. Bush, A. Metals and neuroscience. Curr. Opin. Chem. Biol. 2000, 4, 184-191. [CrossRef]

78. Molina-Holgado, F.; Hider, R.C.; Gaeta, A.; Williams, R.; Francis, P. Metals ions and neurodegeneration. BioMetals 2007, 20, 639-654. [CrossRef]

79. Sayre, L.; Smith, M.; Perry, G. Chemistry and Biochemistry of Oxidative Stress in Neurodegenerative Disease. Curr. Med. Chem. 2001, 8, 721-738. [CrossRef]

80. Fridovich, I. Fundamental Aspects of Reactive Oxygen Species, or What's the Matter with Oxygen? Ann. N. Y. Acad. Sci. 1999, 893, 13-18. [CrossRef]

81. Valko, M.; Rhodes, C.J.; Moncol, J.; Izakovic, M.; Mazur, M. Free radicals, metals and antioxidants in oxidative stress-induced cancer. Chem. Biol. Interact. 2006, 160, 1-40. [CrossRef]

82. Lehmann, I.; Sack, U.; Lehmann, J. Metal ions affecting the immune system. Met. Ions Life Sci. 2011, 8, 157-185. 
83. Rossi-George, A.; Guo, C.-J.; Oakes, B.L.; Gow, A.J. Copper modulates the phenotypic response of activated BV2 microglia through the release of nitric oxide. Nitric Oxide 2012, 27, 201-209. [CrossRef] [PubMed]

84. Rossi-George, A.; Guo, C.-J. Copper disrupts S-nitrosothiol signaling in activated BV2 microglia. Neurochem. Int. 2016, 99, 1-8. [CrossRef]

85. Roberts, B.R.; Ryan, T.M.; Bush, A.I.; Masters, C.L.; Duce, J.A. The role of metallobiology and amyloid- $\beta$ peptides in Alzheimer's disease: Metal ions, $A \beta$ dimers and Alzheimer's disease. J. Neurochem. 2012, 120, 149-166. [CrossRef] [PubMed]

86. Lovell, M.A.; Robertson, J.D.; Teesdale, W.J.; Campbell, J.L.; Markesbery, W.R. Copper, iron and zinc in Alzheimer's disease senile plaques. J. Neurol. Sci. 1998, 158, 47-52. [CrossRef]

87. Leskovjan, A.C.; Lanzirotti, A.; Miller, L.M. Amyloid plaques in PSAPP mice bind less metal than plaques in human Alzheimer's disease. NeuroImage 2009, 47, 1215-1220. [CrossRef]

88. Guilloreau, L.; Combalbert, S.; Sournia-Saquet, A.; Mazarguil, H.; Faller, P. Redox Chemistry of Copper-Amyloid- $\beta$ : The Generation of Hydroxyl Radical in the Presence of Ascorbate is Linked to Redox-Potentials and Aggregation State. ChemBioChem 2007, 8, 1317-1325. [CrossRef] [PubMed]

89. Lee, S.J.C.; Nam, E.; Lee, H.J.; Savelieff, M.G.; Lim, M.H. Towards an understanding of amyloid- $\beta$ oligomers: Characterization, toxicity mechanisms, and inhibitors. Chem. Soc. Rev. 2017, 46, 310-323. [CrossRef]

90. Rajan, M.T.; Rao, K.J.; Mamatha, B.M.; Rao, R.V.; Shanmugavelu, P.; Menon, R.B.; Pavithran, M.V. Quantification of trace elements in normal human brain by inductively coupled plasma atomic emission spectrometry. J. Neurol. Sci. 1997, 146, 153-166. [CrossRef]

91. Cvetkovic, A.; Menon, A.L.; Thorgersen, M.P.; Scott, J.W.; Poole, F.L., II; Jenney, F.E., Jr.; Lancaster, W.A.; Praissman, J.L.; Shanmukh, S.; Vaccaro, B.J.; et al. Microbial metalloproteomes are largely uncharacterized. Nature 2010, 466, 779-782. [CrossRef]

92. Ng, E.; Lind, P.M.; Lindgren, C.; Ingelsson, E.; Mahajan, A.; Morris, A.; Lind, L. Genome-wide association study of toxic metals and trace elements reveals novel associations. Hum. Mol. Genet. 2015, 24, 4739-4745. [CrossRef]

93. Sharma, S.K.; Goloubinoff, P.; Christen, P. Non-native Proteins as Newly-Identified Targets of Heavy Metals and Metalloids. In Cellular Effects of Heavy Metals; Banfalvi, G., Ed.; Springer: Dordrecht, The Netherlands, 2011; pp. 263-274.

94. Kern, M.; Wisniewski, M.; Cabell, L.; Audesirk, G. Inorganic lead and calcium interact positively in activation of calmodulin. Neurotoxicology 2000, 21, 353-363. [PubMed]

95. Bánfalvi, G. Heavy Metals, Trace Elements and Their Cellular Effects. In Cellular Effects of Heavy Metals; Banfalvi, G., Ed.; Springer: Dordrecht, The Netherlands, 2011; pp. 3-28.

96. Nuran Ercal, B.S.P.; Hande Gurer-Orhan, B.S.P.; Nukhet Aykin-Burns, B.S.P. Toxic Metals and Oxidative Stress Part I: Mechanisms Involved in Me-tal induced Oxidative Damage. Curr. Top. Med. Chem. 2001, 1, 529-539. [CrossRef] [PubMed]

97. Aschner, M.; Aschner, J.L. Mercury neurotoxicity: Mechanisms of blood-brain barrier transport. Neurosci. Biobehav. Rev. 1990, 14, 169-176. [CrossRef]

98. Kerper, L.E.; Ballatori, N.; Clarkson, T.W. Methylmercury transport across the blood-brain barrier by an amino acid carrier. Am. J. Physiol. Integr. Comp. Physiol. 1992, 262, R761-R765. [CrossRef]

99. Wagner, C.; Sudati, J.H.; Nogueira, C.W.; Rocha, J.B.T. In vivo and in vitro inhibition of mice thioredoxin reductase by methylmercury. BioMetals 2010, 23, 1171-1177. [CrossRef]

100. Ruipérez, F.; Mujika, J.I.; Ugalde, J.M.; Exley, C.; Lopez, X. Pro-oxidant activity of aluminum: Promoting the Fenton reaction by reducing Fe(III) to Fe(II). J. Inorg. Biochem. 2012, 117, 118-123. [CrossRef]

101. Yokel, R.A. Blood-brain barrier flux of aluminum, manganese, iron and other metals suspected to contribute to metal-induced neurodegeneration. J. Alzheimers Dis. 2006, 10, 223-253. [CrossRef]

102. Exley, C. Human exposure to aluminium. Environ. Sci. Process Impacts 2013, 15, 1807-1816. [CrossRef]

103. Ward, R.J.; Zhang, Y.; Crichton, R.R. Aluminium toxicity and iron homeostasis. J. Inorg. Biochem. 2001, 87, 9-14. [CrossRef]

104. Oteiza, P.I. A Mechanism for the Stimulatory Effect of Aluminum on Iron-Induced Lipid Peroxidation. Arch. Biochem. Biophys. 1994, 308, 374-379. [CrossRef]

105. Yamanaka, K.; Minato, N.; Iwai, K. Stabilization of iron regulatory protein 2, IRP2, by aluminum. FEBS Lett. 1999, 462, 216-220. [CrossRef] 
106. Van Landeghem, G.F.; D’Haese, P.C.; Lamberts, L.V.; De Broe, M.E. Competition of iron and aluminum for transferrin: The molecular basis for aluminum deposition in iron-overloaded dialysis patients? Exp. Nephrol. 1997, 5, 239-245. [PubMed]

107. Wu, Z.; Du, Y.; Xue, H.; Wu, Y.; Zhou, B. Aluminum induces neurodegeneration and its toxicity arises from increased iron accumulation and reactive oxygen species (ROS) production. Neurobiol. Aging 2012, 33, e1-e199. [CrossRef] [PubMed]

108. Guo, G.-W.; Liang, Y.-X. Aluminum-induced apoptosis in cultured astrocytes and its effect on calcium homeostasis. Brain Res. 2001, 888, 221-226. [CrossRef]

109. Canales, J.J.; Corbalán, R.; Montoliu, C.; Llansola, M.; Monfort, P.; Erceg, S.; Hernandez-Viadel, M.; Felipo, V. Aluminium impairs the glutamate-nitric oxide-cGMP pathway in cultured neurons and in rat brain in vivo: Molecular mechanisms and implications for neuropathology. J. Inorg. Biochem. 2001, 87, 63-69. [CrossRef]

110. Banks, W.A.; Kastin, A.J. The aluminum-induced increase in blood-brain barrier permeability to delta-sleep-inducing peptide occurs throughout the brain and is independent of phosphorus and acetylcholinesterase levels. Psychopharmacology 1985, 86, 84-89. [CrossRef] [PubMed]

111. Nehru, B.; Bhalla, P. Reversal of an aluminium induced alteration in redox status in different regions of rat brain by administration of centrophenoxine. Mol. Cell. Biochem. 2006, 290, 185-191. [CrossRef]

112. Sumathi, T.; Shobana, C.; Thangarajeswari, M.; Usha, R. Protective effect of L-Theanine against aluminium induced neurotoxicity in cerebral cortex, hippocampus and cerebellum of rat brain-Histopathological, and biochemical approach. Drug Chem. Toxicol. 2014, 38, 22-31. [CrossRef]

113. Kumar, V.; Gill, K.D. Oxidative stress and mitochondrial dysfunction in aluminium neurotoxicity and its amelioration: A review. NeuroToxicology 2014, 41, 154-166. [CrossRef]

114. Zaky, A.; Mohammad, B.; Moftah, M.Z.; Kandeel, K.M.; Bassiouny, A.R. Apurinic/apyrimidinic endonuclease 1 is a key modulator of aluminum-induced neuroinflammation. BMC Neurosci. 2013, 14, 26. [CrossRef]

115. Corrigan, F.M.; Reynolds, G.P.; Ward, N.I. Hippocampal tin, aluminum and zinc in Alzheimer's disease. BioMetals 1993, 6, 149-154. [CrossRef] [PubMed]

116. Wang, Z.; Wei, X.; Yang, J.; Suo, J.; Chen, J.; Liu, X.; Zhao, X. Chronic exposure to aluminum and risk of Alzheimer's disease: A meta-analysis. Neurosci. Lett. 2016, 610, 200-206. [CrossRef] [PubMed]

117. Maret, W. 1. The Bioinorganic Chemistry of Lead in the Context of Its Toxicity. In Lead-Its Effects on Environment and Health; Sigel, A., Sigel, H., Sigel, R.K.O., Eds.; De Gruyter: Berlin, Germany; Boston, MA, USA, 2017; pp. 1-20.

118. Farkas, E.; Buglyó, P. Lead(II) Complexes of Amino Acids, Peptides, and Other Related Ligands of Biological Interest. In Lead-Its Effects on Environment and Health; Sigel, A., Sigel, H., Sigel, R.K.O., Eds.; De Gruyter: Berlin, Germany; Boston, MA, USA, 2017.

119. Ahamed, M.; Siddiqui, M.K.J. Low level lead exposure and oxidative stress: Current opinions. Clin. Chim. Acta 2007, 383, 57-64. [CrossRef] [PubMed]

120. Maret, W.; Moulis, J.-M. The Bioinorganic Chemistry of Cadmium in the Context of Its Toxicity. In Metal Ions in Life Sciences; Springer: Dordrecht, The Netherlands, 2012; Volume 11, pp. 1-29.

121. Mesna, O.J.; Steffensen, I.-L.; Hjertholm, H.; Andersen, R.A. Accumulation of metallothionein and its multiple forms by zinc, cadmium and dexamethasone in human peripheral $\mathrm{T}$ and B lymphocytes and monocytes. Chem. Biol. Interact. 1995, 94, 225-242. [CrossRef]

122. Krężel, A.; Maret, W. The Functions of Metamorphic Metallothioneins in Zinc and Copper Metabolism. Int. J. Mol. Sci. 2017, 18, 1237. [CrossRef]

123. Peiser, M.; Tralau, T.; Heidler, J.; Api, A.M.; Arts, J.H.E.; Basketter, D.A.; English, J.; Diepgen, T.L.; Fuhlbrigge, R.C.; Gaspari, A.A.; et al. Allergic contact dermatitis: Epidemiology, molecular mechanisms, in vitro methods and regulatory aspects: Current knowledge assembled at an international workshop at BfR, Germany. Cell Mol. Life Sci. 2012, 69, 763-781. [CrossRef]

124. Corsini, E.; Oukka, M.; Pieters, R.; Kerkvliet, N.I.; Ponce, R.; Germolec, D.R. Alterations in regulatory T-cells: Rediscovered pathways in immunotoxicology. J. Immunotoxicol. 2011, 8, 251-257. [CrossRef]

125. Lawrence, D.A.; McCabe, M.J. Immunomodulation by metals. Int. Immunopharmacol. 2002, 2, $293-302$. [CrossRef]

126. Hemdan, N.Y.A.; Emmrich, F.; Adham, K.; Wichmann, G.; Lehmann, I.; El-Massry, A.; Ghoneim, H.; Lehmann, J.; Sack, U. Dose-Dependent Modulation of the In Vitro Cytokine Production of Human Immune Competent Cells by Lead Salts. Toxicol. Sci. 2005, 86, 75-83. [CrossRef] 
127. Hemdan, N.Y.A.; Emmrich, F.; Sack, U.; Wichmann, G.; Lehmann, J.; Adham, K.; Lehmann, I. The in vitro immune modulation by cadmium depends on the way of cell activation. Toxicology 2006, 222, 37-45. [CrossRef]

128. Hemdan, N.Y.A.; Lehmann, I.; Wichmann, G.; Lehmann, J.; Emmrich, F.; Sack, U. Immunomodulation by mercuric chloride in vitro: Application of different cell activation pathways. Clin. Exp. Immunol. 2007, 148, 325-337. [CrossRef]

129. Mandelbrote, B.M.; Stanier, M.W.; Thompson, R.H.S.; Thruston, M.N. Studies on copper metabolism in demyelinating diseases of the central nervous system. Brain 1948, 71, 212-228. [CrossRef] [PubMed]

130. Tamburo, E.; Varrica, D.; Dongarrà, G.; Grimaldi, L.M.E. Trace Elements in Scalp Hair Samples from Patients with Relapsing-Remitting Multiple Sclerosis. PLoS ONE 2015, 10, e0122142. [CrossRef] [PubMed]

131. Giacoppo, S.; Galuppo, M.; Calabrò, R.S.; D'Aleo, G.; Marra, A.; Sessa, E.; Bua, D.G.; Potorti, A.G.; Dugo, G.; Bramanti, P.; et al. Heavy Metals and Neurodegenerative Diseases: An Observational Study. Biol. Trace Elem. Res. 2014, 161, 151-160. [CrossRef] [PubMed]

132. Palm, R.; Hallmans, G. Zinc and copper in multiple sclerosis. J. Neurol. Neurosurg. Psychiatry 1982, 45, 691-698. [CrossRef]

133. Pawlitzki, M.; Uebelhör, J.; Sweeney-Reed, C.; Stephanik, H.; Hoffmann, J.; Lux, A.; Reinhold, D. Lower Serum Zinc Levels in Patients with Multiple Sclerosis Compared to Healthy Controls. Nutrients 2018, $10,967$. [CrossRef]

134. Nasrabadi, M.N.; Forghani, D.; Shahabi, I.; Shirini, R. Determination of trace elements in blood samples of patients affected by multiple sclerosis from Iran by neutron activation analysis. J. Radioanal. Nucl. Chem. 2012, 293, 479-482. [CrossRef]

135. De Riccardis, L.; Buccolieri, A.; Muci, M.; Pitotti, E.; De Robertis, F.; Trianni, G.; Manno, D.; Maffia, M. Copper and ceruloplasmin dyshomeostasis in serum and cerebrospinal fluid of multiple sclerosis subjects. Biochim. Biophys. Acta (BBA) Mol. Basis Dis. 2018, 1864, 1828-1838. [CrossRef]

136. Ghazavi, A.; Kianbakht, S.; Ghasami, K.; Mosayebi, G. High copper and low zinc serum levels in Iranian patients with multiple sclerosis: A case control study. Clin. Lab. 2012, 58, 161-164.

137. Juybari, K.B.; Ebrahimi, G.; Momeni Moghaddam, M.A.; Asadikaram, G.; Torkzadeh-Mahani, M.; Akbari, M.; Mirzamohammadi, S.; Karimi, A.; Nematollahi, M.H. Evaluation of serum arsenic and its effects on antioxidant alterations in relapsing-remitting multiple sclerosis patients. Mult. Scler. Relat. Disord. 2018, 19, 79-84. [CrossRef]

138. Dehghanifiroozabadi, M.; Noferesti, P.; Amirabadizadeh, A.; Nakhaee, S.; Aaseth, J.; Noorbakhsh, F.; Mehrpour, O. Blood lead levels and multiple sclerosis: A case-control study. Mult. Scler. Relat. Disord. 2019, 27, 151-155. [CrossRef] [PubMed]

139. Attar, A.M.; Kharkhaneh, A.; Etemadifar, M.; Keyhanian, K.; Davoudi, V.; Saadatnia, M. Serum Mercury Level and Multiple Sclerosis. Biol. Trace. Elem. Res. 2012, 146, 150-153. [CrossRef]

140. Alimonti, A.; Ristori, G.; Giubilei, F.; Stazi, M.A.; Pino, A.; Visconti, A.; Brescianini, S.; Monti, M.S.; Forte, G.; Stanzione, P.; et al. Serum chemical elements and oxidative status in Alzheimer's disease, Parkinson disease and multiple sclerosis. NeuroToxicology 2007, 28, 450-456. [CrossRef]

141. Janghorbani, M.; Shaygannejad, V.; Hakimdavood, M.; Salari, M. Trace Elements in Serum Samples of Patients with Multiple Sclerosis. Athens J. Health 2017, 4, 145-154. [CrossRef]

142. De Oliveira, M.; Gianeti, T.M.R.; da Rocha, F.C.G.; Lisboa-Filho, P.N.; Piacenti-Silva, M. A preliminary study of the concentration of metallic elements in the blood of patients with multiple sclerosis as measured by ICP-MS. Sci. Rep. 2020, 10, 13112. [CrossRef] [PubMed]

143. Siotto, M.; Filippi, M.M.; Simonelli, I.; Landi, D.; Ghazaryan, A.; Vollaro, S.; Ventriglia, M.; Pasqualetti, P.; Rongioletti, M.C.A.; Squitti, R.; et al. Oxidative Stress Related to Iron Metabolism in Relapsing Remitting Multiple Sclerosis Patients With Low Disability. Front. Neurosci. 2019, 13, 86. [CrossRef] [PubMed]

144. Popescu, B.F.; Frischer, J.M.; Webb, S.M.; Tham, M.; Adiele, R.C.; Robinson, C.A.; Fitz-Gibbon, P.D.; Weigand, S.D.; Metz, I.; Nehzati, S.; et al. Pathogenic implications of distinct patterns of iron and zinc in chronic MS lesions. Acta Neuropathol. 2017, 134, 45-64. [CrossRef]

145. Yao, B.; Hametner, S.; van Gelderen, P.; Merkle, H.; Chen, C.; Lassmann, H.; Duyn, J.H.; Bagnato, F. 7 Tesla Magnetic Resonance Imaging to Detect Cortical Pathology in Multiple Sclerosis. PLoS ONE 2014, 9, e108863. [CrossRef] 
146. Khalil, M.; Langkammer, C.; Pichler, A.; Pinter, D.; Gattringer, T.; Bachmaier, G.; Ropele, S.; Fuchs, S.; Enzinger, C.; Fazekas, F. Dynamics of brain iron levels in multiple sclerosis: A longitudinal 3T MRI study. Neurology 2015, 84, 2396-2402. [CrossRef]

147. Stephenson, E.; Nathoo, N.; Mahjoub, Y.; Dunn, J.F.; Yong, V.W. Iron in multiple sclerosis: Roles in neurodegeneration and repair. Nat. Rev. Neurol. 2014, 10, 459-468. [CrossRef]

148. Bagnato, F.; Hametner, S.; Welch, E.B. Visualizing iron in multiple sclerosis. Magn. Reason. Imaging 2013, 31, 376-384. [CrossRef] [PubMed]

149. Dal-Bianco, A.; Grabner, G.; Kronnerwetter, C.; Weber, M.; Höftberger, R.; Berger, T.; Auff, E.; Leutmezer, F.; Trattnig, S.; Lassmann, H.; et al. Slow expansion of multiple sclerosis iron rim lesions: Pathology and $7 \mathrm{~T}$ magnetic resonance imaging. Acta Neuropathol. 2017, 133, 25-42. [CrossRef] [PubMed]

150. Bagnato, F.; Hametner, S.; Yao, B.; van Gelderen, P.; Merkle, H.; Cantor, F.K.; Lassmann, H.; Duyn, J.H. Tracking iron in multiple sclerosis: A combined imaging and histopathological study at 7 Tesla. Brain 2011, 134, 3602-3615. [CrossRef]

151. Magliozzi, R.; Hametner, S.; Facchiano, F.; Marastoni, D.; Rossi, S.; Castellaro, M.; Poli, A.; Lattanzi, F.; Visconti, A.; Nicholas, R. Iron homeostasis, complement, and coagulation cascade as CSF signature of cortical lesions in early multiple sclerosis. Ann. Clin. Transl. Neurol. 2019, 6, 2150-2163. [CrossRef]

152. Zivadinov, R.; Tavazzi, E.; Bergsland, N.; Hagemeier, J.; Lin, F.; Dwyer, M.G.; Carl, E.; Kolb, C.; Hojnacki, D. Ramasamy, D. Brain Iron at Quantitative MRI Is Associated with Disability in Multiple Sclerosis. Radiology 2018, 289, 487-496. [CrossRef] [PubMed]

153. Hagemeier, J.; Ramanathan, M.; Schweser, F.; Dwyer, M.G.; Lin, F.; Bergsland, N.; Weinstock-Guttman, B.; Zivadinov, R. Iron-related gene variants and brain iron in multiple sclerosis and healthy individuals. NeuroImage Clin. 2018, 17, 530-540. [CrossRef] [PubMed]

154. Yasui, M.; Yase, Y.; Ando, K.; Adachi, K.; Mukoyama, M.; Ohsugi, K. Magnesium concentration in brains from multiple sclerosis patients. Acta. Neurol. Scand. 2009, 81, 197-200. [CrossRef]

155. Melo, T.M.; Larsen, C.; White, L.R.; Aasly, J.; Sjobakk, T.E.; Flaten, T.P.; Sonnewald, U.; Syversen, T. Manganese, Copper, and Zinc in Cerebrospinal Fluid from Patients with Multiple Sclerosis. Biol. Trace Element Res. 2003, 93, 1-8. [CrossRef]

156. Bredholt, M.; Frederiksen, J.L. Zinc in Multiple Sclerosis: A Systematic Review and Meta-Analysis. ASN Neuro 2016, 8. [CrossRef]

157. Van Wart, H.E.; Birkedal-Hansen, H. The cysteine switch: A principle of regulation of metalloproteinase activity with potential applicability to the entire matrix metalloproteinase gene family. Proc. Natl. Acad. Sci. USA 1990, 87, 5578-5582. [CrossRef]

158. Penkowa, M.; Espejo, C.; Ortega-Aznar, A.; Hidalgo, J.; Montalban, X.; Martínez Cáceres, E.M. Metallothionein expression in the central nervous system of multiple sclerosis patients. Cell Mol. Life Sci. 2003, 60, 1258-1266. [CrossRef] [PubMed]

159. Yong, V.W.; Zabad, R.K.; Agrawal, S.; Goncalves DaSilva, A.; Metz, L.M. Elevation of matrix metalloproteinases (MMPs) in multiple sclerosis and impact of immunomodulators. J. Neurol. Sci. 2007, 259, 79-84. [CrossRef] [PubMed]

160. Lindberg, R.L.P. The expression profile of matrix metalloproteinases (MMPs) and their inhibitors (TIMPs) in lesions and normal appearing white matter of multiple sclerosis. Brain 2001, 124, 1743-1753. [CrossRef] [PubMed]

161. Cossins, J.A.; Clements, J.M.; Ford, J.; Miller, K.M.; Pigott, R.; Vos, W.; Van der Walk, P.; De Groot, C.J. Enhanced expression of MMP-7 and MMP-9 in demyelinating multiple sclerosis lesions. Acta Neuropathol. 1997, 94, 590-598. [CrossRef] [PubMed]

162. Maeda, A.; Sobel, R.A. Matrix Metalloproteinases in the Normal Human Central Nervous System, Microglial Nodules, and Multiple Sclerosis Lesions. J. Neuropathol. Exp. Neurol. 1996, 55, 300-309. [CrossRef]

163. Bar-Or, A. Analyses of all matrix metalloproteinase members in leukocytes emphasize monocytes as major inflammatory mediators in multiple sclerosis. Brain 2003, 126, 2738-2749. [CrossRef]

164. Gray, E.; Thomas, T.L.; Betmouni, S.; Scolding, N.; Love, S. Elevated Matrix Metalloproteinase- 9 and Degradation of Perineuronal Nets in Cerebrocortical Multiple Sclerosis Plaques. J. Neuropathol. Exp. Neurol. 2008, 67, 888-899. [CrossRef]

165. Mold, M.; Chmielecka, A.; Rodriguez, M.; Thom, F.; Linhart, C.; King, A.; Exley, C. Aluminium in Brain Tissue in Multiple Sclerosis. Int. J. Environ. Res. Public Health 2018, 15, 1777. [CrossRef] 
166. Linhart, C.; Davidson, D.; Pathmanathan, S.; Kamaladas, T.; Exley, C. Aluminium in Brain Tissue in Non-neurodegenerative/Non-neurodevelopmental Disease: A Comparison with Multiple Sclerosis. Expo Health 2020, 12, 863-868. [CrossRef]

167. Sensi, S.L.; Granzotto, A.; Siotto, M.; Squitti, R. Copper and Zinc Dysregulation in Alzheimer's Disease. Trends Pharmacol. Sci. 2018, 39, 1049-1063. [CrossRef]

168. Pfaender, S.; Grabrucker, A.M. Characterization of biometal profiles in neurological disorders. Metallomics 2014, 6, 960-977. [CrossRef] [PubMed]

169. Lobinski, R.; Becker, J.S.; Haraguchi, H.; Sarkar, B. Metallomics: Guidelines for terminology and critical evaluation of analytical chemistry approaches (IUPAC Technical Report). Pure Appl. Chem. 2010, 82, 493-504. [CrossRef]

170. Nakazawa, E.; Ikemoto, T.; Hokura, A.; Terada, Y.; Kunito, T.; Tanabe, S.; Nakai, I. The presence of mercury selenide in various tissues of the striped dolphin: Evidence from $\mu-X R F-X R D$ and XAFS analyses. Metallomics 2011, 3, 719. [CrossRef] [PubMed]

171. Korbas, M.; O’Donoghue, J.L.; Watson, G.E.; Pickering, I.J.; Singh, S.P.; Myers, G.J.; Clarkson, T.W.; George, G.N. The Chemical Nature of Mercury in Human Brain Following Poisoning or Environmental Exposure. ACS. Chem. Neurosci. 2010, 1, 810-818. [CrossRef] [PubMed]

172. Bacquart, T.; Devès, G.; Carmona, A.; Tucoulou, R.; Bohic, S.; Ortega, R. Subcellular Speciation Analysis of Trace Element Oxidation States Using Synchrotron Radiation Micro-X-ray Absorption Near-Edge Structure. Anal. Chem. 2007, 79, 7353-7359. [CrossRef] [PubMed]

173. Brown, R.J.C.; Milton, M.J.T. Analytical techniques for trace element analysis: An overview. TrAC Trends Anal. Chem. 2005, 24, 266-274. [CrossRef]

174. Ackerman, C.M.; Lee, S.; Chang, C.J. Analytical Methods for Imaging Metals in Biology: From Transition Metal Metabolism to Transition Metal Signaling. Anal. Chem. 2017, 89, 22-41. [CrossRef]

175. McRae, R.; Bagchi, P.; Sumalekshmy, S.; Fahrni, C.J. In Situ Imaging of Metals in Cells and Tissues. Chem. Rev. 2009, 109, 4780-4827. [CrossRef]

176. Stewart, T.J. Across the spectrum: Integrating multidimensional metal analytics for in situ metallomic imaging. Metallomics 2019, 11, 29-49. [CrossRef]

177. Busser, B.; Moncayo, S.; Coll, J.-L.; Sancey, L.; Motto-Ros, V. Elemental imaging using laser-induced breakdown spectroscopy: A new and promising approach for biological and medical applications. Coord. Chem. Rev. 2018, 358, 70-79. [CrossRef]

178. Braidy, N.; Poljak, A.; Marjo, C.; Rutlidge, H.; Rich, A.; Jayasena, T.; Inestrosa, N.C.; Sachdev, P. Metal and complementary molecular bioimaging in Alzheimer's disease. Front. Aging Neurosci. 2014, 6, 138. [CrossRef] [PubMed]

179. Ortega, R.; Cloetens, P.; Devès, G.; Carmona, A.; Bohic, S. Iron Storage within Dopamine Neurovesicles Revealed by Chemical Nano-Imaging. PLoS ONE 2007, 2, e925. [CrossRef]

180. Keogh, M.J.; Morris, C.M.; Chinnery, P.F. Neuroferritinopathy. Int. Rev. Neurobiol. 2013, 110, 91-123. [PubMed]

181. Carboni, E.; Nicolas, J.-D.; Töpperwien, M.; Stadelmann-Nessler, C.; Lingor, P.; Salditt, T. Imaging of neuronal tissues by X-ray diffraction and x-ray fluorescence microscopy: Evaluation of contrast and biomarkers for neurodegenerative diseases. Biomed. Opt. Express 2017, 8, 4331. [CrossRef]

182. Gardner, B.; Dieriks, B.V.; Cameron, S.; Mendis, L.H.S.; Turner, C.; Faull, R.L.M.; Curtis, M.A. Metal concentrations and distributions in the human olfactory bulb in Parkinson's disease. Sci. Rep. 2017, 7, 10454. [CrossRef] [PubMed]

183. Portbury, S.; Adlard, P. Zinc Signal in Brain Diseases. Int. J. Mol. Sci. 2017, 18, 2506. [CrossRef] [PubMed]

184. Weigel, K.J.; Lynch, S.G.; Levine, S.M. Iron Chelation and Multiple Sclerosis. ASN Neuro 2013, 6. [CrossRef] [PubMed]

Publisher's Note: MDPI stays neutral with regard to jurisdictional claims in published maps and institutional affiliations. 